\title{
Technology of Using Linguistic Markers in the Process of Art Therapy Training
}

\author{
Tecnologia de Uso de Marcadores Linguísticos no Processo de \\ Treinamento em Arteterapia
}

\section{Tecnología de Uso de Marcadores Lingüísticos en el Proceso de Formación en Arteterapia}

\author{
Marina Georgiyevna Sergeeva ${ }^{1}$ (D), Andrei Anatolievich Kochin ${ }^{1}$ (D), \\ Dmitry Vladimirovich Lukashenko ${ }^{1}$ (D) , Ekaterina Vladislavovna Kozhina $^{2}$
}

\footnotetext{
${ }^{1}$ Research Institute of the Federal Penitentiary Service of the Russian Federation, Moscow, Russia.

${ }^{2}$ Peoples' Friendship University of Russia (RUDN University), Moscow, Russia.
}

Corresponding author:

Marina Georgiyevna Sergeeva

Email: sergeeva198262@mail.ru

How to cite: Sergeeva, M. G., Kochin, A. A., Lukashenko, D. V., \& Kozhina, E. V. (2021). Technology of Using Linguistic Markers in the Process of Art Therapy Training. Revista Tempos e Espaços em Educação, 14(33), e16264.

http://dx.doi.org/10.20952/revtee.v14i33.16264

\section{ABSTRACT}

The article examines the issues of students' reflexivity, the impact of the reflexivity on the educational process and psychological health, the importance of its development. The purpose of the article is the theoretical and empirical study of students' reflexivity through its expression in various linguistic markers, the importance of reflexivity in the personal and potential professional development of students. The research methodology and its algorithm were selected due to the purpose of the study. Experimental work included a complex psychological and pedagogical experiment, diagnosing the stated parameters and their subsequent statistical analysis. The study of students' reflexivity was carried out on the basis of the Institute of Foreign Languages of the Federal State Autonomous Educational Institution of Higher Education "The Peoples' Friendship University of Russia "(RUDN). Research sampling: reports (essays) of the 1-4 year students. The target group consisted of 98 students, divided into seven subgroups. The results of the study allowed us to conclude that there is a significant interdependence between linguistic markers and students' reflexivity. Psychological health is a necessary and important condition for the full development of a personality. On the one hand, it ensures the adequate fulfillment of social roles, on the other hand, it creates the possibility of continuous personal and professional development throughout life. Supporting psychological health is one of the urgent tasks in the young age, the most important stage in the formation of a personality. Reflexivity of students, appearing in the 
process of consulting or training work, manifests itself, first of all, in speech processes. Group reflexivity, in turn, is the main method of psychological training, since it helps to comprehend and integrate the ongoing experience.

Keywords: Reflexivity. Reflexive processes. Linguistic markers. Psychological health.

\section{RESUMO}

O artigo examina as questões da reflexividade dos alunos, o impacto da reflexividade no processo educacional e na saúde psicológica, a importância do seu desenvolvimento. O objetivo do artigo é o estudo teórico e empírico da reflexividade dos alunos através da sua expressão em vários marcadores linguísticos, a importância da reflexividade no desenvolvimento pessoal e potencial profissional dos alunos. A metodologia de pesquisa e seu algoritmo foram selecionados em função do objetivo do estudo. $O$ trabalho experimental incluiu um experimento psicológico e pedagógico complexo, diagnosticando os parâmetros declarados e sua posterior análise estatística. $O$ estudo da reflexividade dos alunos foi realizado com base no Instituto de Línguas Estrangeiras da Instituição Educacional Autônoma do Estado Federal de Educação Superior "The Peoples' Friendship University of Russia "(RUDN). Amostragem da pesquisa: relatórios (ensaios) dos alunos de 1 a 4 anos. 0 grupo alvo consistia em 98 alunos, divididos em sete subgrupos. Os resultados do estudo permitiram concluir que existe uma interdependência significativa entre os marcadores linguísticos e a reflexividade dos alunos. A saúde psicológica é uma condição necessária e importante para o pleno desenvolvimento de uma personalidade. Por um lado, garante o cumprimento adequado dos papéis sociais, por outro, cria a possibilidade de desenvolvimento pessoal e profissional contínuo ao longo da vida. Apoiar a saúde psicológica é uma das tarefas urgentes da juventude, a etapa mais importante da formação de uma personalidade. A reflexividade dos alunos, que surge no processo de consultoria ou trabalho de formação, manifesta-se, antes de mais nada, nos processos de fala. A reflexividade de grupo, por sua vez, é o principal método de treinamento psicológico, pois ajuda a compreender e integrar a experiência em curso.

Palavras-chave: Reflexividade. Processos reflexivos. Marcadores linguísticos. Saúde psicológica.

\section{RESUMEN}

El artículo examina los problemas de la reflexividad de los estudiantes, el impacto de la reflexividad en el proceso educativo y la salud psicológica, la importancia de su desarrollo. El propósito del artículo es el estudio teórico y empírico de la reflexividad de los estudiantes a través de su expresión en diversos marcadores lingüísticos, la importancia de la reflexividad en el desarrollo personal y potencial profesional de los estudiantes. La metodología de investigación y su algoritmo fueron seleccionados en función del propósito del estudio. El trabajo experimental incluyó un complejo experimento psicológico y pedagógico, diagnosticando los parámetros planteados y su posterior análisis estadístico. El estudio de la reflexividad de los estudiantes se llevó a cabo sobre la base del Instituto de Lenguas Extranjeras de la Institución Educativa Autónoma de Educación Superior del Estado Federal "Universidad de la Amistad de los Pueblos de Rusia" (RUDN). Muestreo de investigación: informes (ensayos) de los estudiantes de 1-4 años. El grupo objetivo estaba formado por 98 estudiantes, divididos en siete subgrupos. Los resultados del estudio nos permitieron concluir que existe una interdependencia significativa entre los marcadores lingüísticos y la reflexividad de los estudiantes. La salud psicológica es una condición necesaria e importante para el pleno desarrollo de la personalidad. Por un lado, asegura el adecuado cumplimiento de los roles sociales, por otro lado, crea la posibilidad de un desarrollo personal y profesional continuo a lo largo de la vida. Apoyar la salud psicológica es una de las tareas urgentes en la edad temprana, la etapa más importante en la formación de una personalidad. La reflexividad de los estudiantes, que aparece en el proceso de trabajo de consultoría o formación, se manifiesta, en primer lugar, en los procesos de 
habla. La reflexividad grupal, a su vez, es el principal método de entrenamiento psicológico, ya que ayuda a comprender e integrar la experiencia en curso.

Palabras clave: Reflexividad. Procesos reflexivos. Marcadores lingüísticos. Salud psicológica.

\section{INTRODUCTION}

A number of authors use the concepts of "psychological health" and "personality maturity" synonymously (Sharonova et al., 2018; Blinova et al., 2018; Tekucheva, 2006; Tekucheva \& Gromova, 2016). In recent years, in Russia the focus has been on the work of the psychological services of educational institutions. Russian psychologist I.V. Dubrovina (2009) notes that psychological health is the goal of the psychological service of an educational institution. Reflexivity is one of the most important components of psychological health (Dolzhich \& Dmitrichenkova, 2018). Reflexivity of students, appearing in the process of consulting or training work, manifests itself, first of all, in speech processes. Group reflexivity, in turn, is the main method of psychological training, since it helps to comprehend and integrate the ongoing experience (Tekucheva, 2018). Many psychologists and education specialists believe that reflexivity plays a special role in the development of creativity, contributing to the personal growth, acting as a kind of mirror that reflects the changes taking place in a person (Gorev et al., 2018; Volkova \& Panchenko, 2018; Gromova \& Tekucheva, 2017).

The initial task of this study was to reveal the contradiction between the need to introduce a reflexive approach in teaching university students and the lack of reflexivity assessment tools adapted for this group of students, in particular, the identification of specific linguistic markers.

\section{LITERATURE REVIEW}

Activation of potentialities, realization of abilities, needs, interests of a student is the main task of the educational process. Reflexivity is the basic device of a person, thanks to which it becomes possible to realize and regulate his/her life. Self-analysis and self-esteem of one's own personality are indissolubly connected with reflexivity, which ensures the direct involvement of the subject in the situation, analysis of what is happening, and comprehension of its elements. Reflexivity allows the subject to correlate actions with the situation, control and coordinate elements of activity depending on changing conditions, analyze the events that occurred, actions committed in the past, plan future events and most effectively predict possible results (Vasbieva et al., 2018).

In the educational process, any projects, including educational ones, at any level of their hierarchy, come to the end with reflection, that is, "turning back", comparing, comprehending, evaluating. Throughout the entire period of training, reflexive processes should permeate the activities of students (Bírová et al., 2018). If in the learning process the leading role is played by the reflexive analysis of one's own consciousness and activity, then in the teaching aspect it is necessary to develop reflexivity as the understanding of interpersonal communication. This is especially true for teenagers and young people, when communication with peers comes to the fore. Thus, the purposeful formation of reflexive skills is one of the urgent problems of secondary and higher education (Tekucheva \& Gromova, 2015).

The formation of a socially mature personality occurs on the basis of reflexive processes and is associated with adolescence. College students begin their studies at the age of 15-16, during their late teens. Studying the individual psychological development of a person, an outstanding Russian psychologist B.G. Ananiev (1996) singled out the age of 18-25 years as the period of the greatest concentration of constructive ontogenetic shifts, acceleration of maturation and slowing down of aging processes. Thus, during the period of study at the university, an intensive process of the social maturity development takes place, in which reflexivity plays the most important role. 
Reflexivity is the central link in the regulatory process. During university training, the students regularly have periods of knowledge testing in the form of term tests and exams, which, due to their high importance, cause mental stress and need psychological regulation. Studying the influence of reflexivity on the mental states of students, it was found that with an increase in the level of reflexivity, the intensity of short-term states increases, and the severity of long-term states, on the contrary, decreases. Students with a high level of reflexivity are characterized by highintensity positive mental states and low-intensity negative mental states. Thus, reflexivity performs a transforming function in the regulatory process (Ananiev, 1996).

Recently, the psychological services have been introduced into the activities of all educational organizations, including higher education. Under the influence of the psychological service, the modern education system considers the psychological health of students as a priority problem and looks for the ways to solve it.

The psychological health of students is determined by both the level of mental development and a certain level of psychological literacy (Leontiev, 2011). The development of reflexivity plays an important role in the formation of psychological health.

Due to the fact that reflexivity is characterized by the degree of representation of its inner content in the psyche, the degree of self-representation deserves special attention. Respectively, the indicators of self-representation were considered in this research (Karpov, 2006). The linguistic indicators and their characteristics are given in Table 1.

Table 1. Linguistic indicators of reflexivity.

\begin{tabular}{ll}
\hline Indicators & Mark physiological sensations in organism \\
\hline Bodily-somatic & Mark psycho-physiological bodily sensations \\
Bodily-energetic & Mark emotions stimulating activity, \\
Emotionally-sthenic & boosting energy, prompting action \\
Emotionally-asthenic & Mark emotions leading to stiffness and passivity \\
Emotionally-positive & Mark emotions of positive modality \\
Emotionally-negative & Mark emotions of negative modality \\
Emotionally-intellectual & Mark the emotions accompanying intellectual activity \\
Cognitive primary & Mark thoughts that indicate prerequisites for awareness \\
Cognitive-secondary & Mark thoughts that indicate awareness \\
Self-factor & Mark the presence of personal experience
\end{tabular}

A study on the use of linguistic markers was published in 2007 and 2016 (University of Texas at Austin, Cindy K. Chung, James W. Pennebaker). The original intent of this program was to better understand how people used language when writing about emotional upheavals in their lives. Starting in the 1980s, the researchers discovered that when people wrote about traumatic experiences for 3-4 days for as little as 15-30 minutes per day, they subsequently exhibited improvements in physical health. Then a text analysis program Linguistic Inquiry and Word Count allowed the researchers to see what word types ultimately correlated with health changes. The article focused on the analyses of approximately 95,000 text files representing over 80,000 different people (Tekucheva, 2006). 
It was found that words expressing negative emotions were more common in the texts of people with anxiety and depression than in people with suicidal thoughts. Also the study included the texts from participants who stated that they had recovered from their depressive bouts. The number of words expressing positive emotions was about $70 \%$ higher.

The researchers noted that computer word processing technologies would continue to improve. Now in many countries the work has begun on using computers to pinpoint increasingly specific subcategories of mental health problems, such as perfectionism, self-esteem problems and social anxiety.

\section{PROPOSED METHODOLOGY}

Purpose of the study: to identify the differences in the presented linguistic markers in the essays of students - participants in art therapy groups with different types and levels of reflexivity.

Object: essays by students participating in art therapy trainings.

Subject: linguistic markers of reflexivity of students - participants in art therapy trainings.

Research sampling: reports (essays) of the 1-4 year students.

The target group consisted of 98 students, divided into subseven groups.

The study of students' reflexivity was carried out on the basis of the Institute of Foreign Languages of the Federal State Autonomous Educational Institution of Higher Education "The Peoples' Friendship University of Russia "(RUDN).

The stages of the experimental work were as follows:

- revealing the level of reflexivity of students according to the methods of A.V. Karpov (2006) and D.A. Leontiev (2011);

- conducting art therapy trainings, observing the strategies for completing tasks;

- content analysis of the essays, clarification of the dictionary of linguistic markers, compiled in the previous works;

- correlation analysis of linguistic markers and the level of reflexivity;

- as an additional line of research, correlation of learning strategies with each type of reflexivity.

As a result of studying the theoretical material, we formulated the hypotheses for carrying out the experimental work.

1) In essay texts written by students having high reflexivity level, linguistic markers are presented differently than in essays written by students having low reflexivity level.

2) In essay texts written by students with high systemic reflexivity, linguistic markers are presented differently than in the texts of students with high introspection or quasi-reflexivity.

To achieve this goal and confirm the hypotheses put forward, the research tasks and the following diagnostic methods were defined:

1) methods for determining the level of reflexivity by A.V. Karpov;

2) differential test of reflexivity by D.A. Leontiev.

Table 2. Algorithm of actions in the course of the experiment.

\section{Algorithm of actions}

1) to identify the level of reflexivity of students according to the methods of A.V. Karpov and D. A. Leontiev

2) based on the results of art therapy training, to determine strategies for performing exercises and collect feedback in the form of an essay

3) to conduct a linguistic content analysis of the essay texts of students participating in the art therapy training

4) to compile a dictionary and group it in accordance with the classifier of linguistic markers found in students' essays based on Table 1

5) to investigate and correlate the differences in the presented linguistic markers as indicators of reflexivity in the essays by students with different methods of measuring reflexivity

6 ) to determine the links between decreases or increases in reflexivity and training strategies 


\section{RESULT ANALYSIS}

At the initial stage of the study, a diagnostic measurement of the reflexivity level was carried out according to the methods of A.V. Karpov and D.A. Leontiev. The diagram illustrating the distribution of the percentage of students with different reflexivity levels according to the Karpov method is shown in Figure 1.

As can be seen from the presented diagram, $11.5 \%$ of students have low reflexivity, $16.1 \%$ high and $72.4 \%$ - medium.

Figure 1. The percentage of students with different reflexivity levels (low, medium, high).

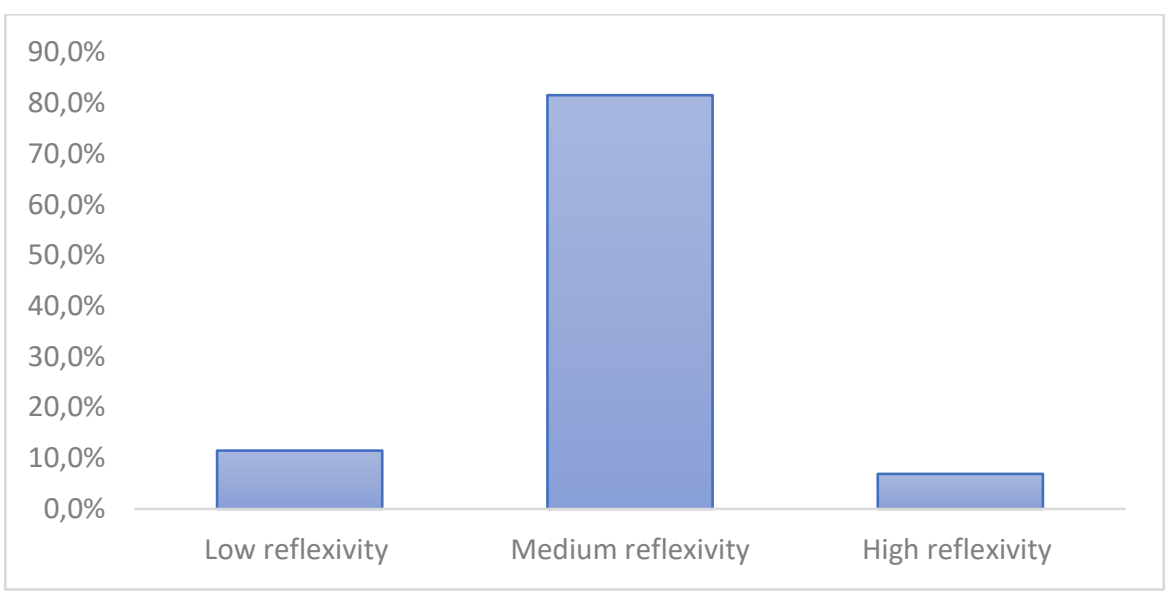

Based on these data, it was concluded that among those who participated in the art therapy trainings, there were more medium-reflexive students and less often having a high reflexivity level and low-reflexive students, and fewer low-reflexive students. Among psychology students, 25\% were low-reflexive students, $50 \%$ were medium-reflexive students, and $25 \%$ were students having high reflexivity level.

Further, art therapy trainings were held. The purpose of trainings for students was practical development of reflexivity skills, tracking changes in their psychological state.

The essays (98 students) were taken for the experimental research, texts of 135 pages were studied, with a total volume of 15,000 words. As a result, the reports were separated (73 out of 98 students or $74 \%$ ) containing information about the personal experiences of the participants. That is, $26 \%$ of students wrote reports formally, without using their reflexive abilities (Figure 2 ).

Figure 2. Percentage of the essays that do not contain personal experience.

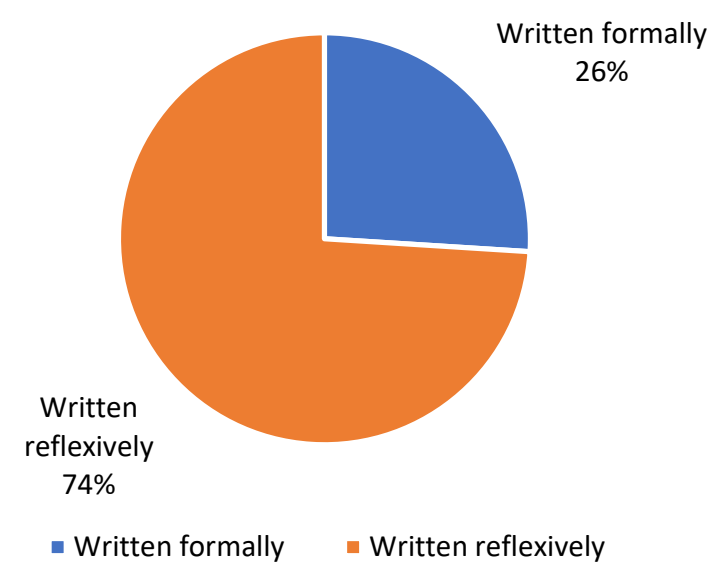


Using content analysis of the essays containing personal experiences of students, 276 linguistic markers (words and word groups) were selected, presumably indicating reflexivity.

The dictionary was compiled using the MaxQDA2018 program, which was developed for computerized analysis of qualitative, mixed, textual and multimedia data in educational, scientific and private organizations. With the help of this program, using all essay texts suitable for processing, a dictionary of word frequency was compiled.

Subsequently, linguistic markers were classified according to the features developed in the work of O.S. Chalikova (2017) and D.E. Koldochevsky (2017) and presented in Table 1.

The classifier and examples of linguistic markers that were selected as a result of content analysis (Table 3 ) include the reflection of the activity of various psychical levels in written speech and channels of reflected information. The dictionary of linguistic markers consisting of 276 markers was compiled.

Table 3. Classifier of linguistic markers as indicators of reflexivity.

\begin{tabular}{ll}
$\begin{array}{l}\text { Group (subgroup) of linguistic Number of markers } \\
\text { markers }\end{array}$ & Examples \\
\hline
\end{tabular}

1. Bodily

$1.1 \quad$ Bodily-somatic

1.2 Bodily-energetic

\section{Emotional}

2.1 Emotionally-sthenic

2.2 Emotionally-asthenic

2.3 Emotionally-positive

2.4 Emotionally-negative

2.5 Emotionally-intellectual

3. Cognitive

3.1 Cognitive primary

3.2 Cognitive secondary

4. Self-factor

\section{4}

27

7

124

16

3

46

45

14

116

34

82

2 hands, cold, motion

fatigue, power, load

boil, madly, overwhelm

despair, entrancement

pleasantly, relief, positive

trouble, fear, loneliness

excitement, courtliness

desire, association, remind

conclusion, comprehension, understanding

I, we

Further, we carried out a correlation analysis of linguistic markers and the level of reflexivity according to the methods of A.V. Karpov and D.A. Leontiev. The calculation of Spearman's rank correlation coefficient was carried out between the scale of the Karpov method for studying the level of reflexivity and the occurrence of linguistic markers of various types in students' essays according to the classifier.

The results showed a correlation $(r=0.49)$ between the level of reflexivity and the total number of markers. The correlation is positive, respectively, the higher the level of reflexivity, the more often markers are found in students' essays.

There is a correlation between emotional markers and the level of reflexivity according to the Karpov method $(r=0.36)$. The data obtained indicate that the more often emotional markers are found in students' essays, the higher the reflexivity according to the Karpov method. 
The highest correlation $(r=0.42$ ) was shown by cognitive markers and the level of reflexivity according to the Karpov method. That is, the higher the reflexivity, the more often they occur in the texts describing cognitive processes.

Also in the students' essays there was a positive correlation between the level of reflexivity according to the Karpov method, cognitive primary and cognitive secondary markers $(r=0.37)$. This means that the higher the level of reflexivity, the more often cognitive primary and cognitive secondary markers are found.

Next, a one-factor variance analysis was carried out in order to identify the effect of reflexivity on the color palette. No effect was found.

For a visual demonstration of the results, we plotted the scattering depending on the color palette choice in the drawings on the reflexivity scale (Figure 3).

Rainbow palettes are found in the drawings of the training participants with medium reflexivity, pastel ones - with medium to high. Reptilian and natural palettes are found in the drawings of the participants with low, medium, and high reflexivity. At the same time, a reptilian palette prevails in the drawings of participants in art therapy training with low reflexivity. In the drawings of participants with high reflexivity, natural palette is more common.

Figure 3. Scattering on the reflexivity scale by A.V. Karpov, depending on the choice of the color palette in the drawings.

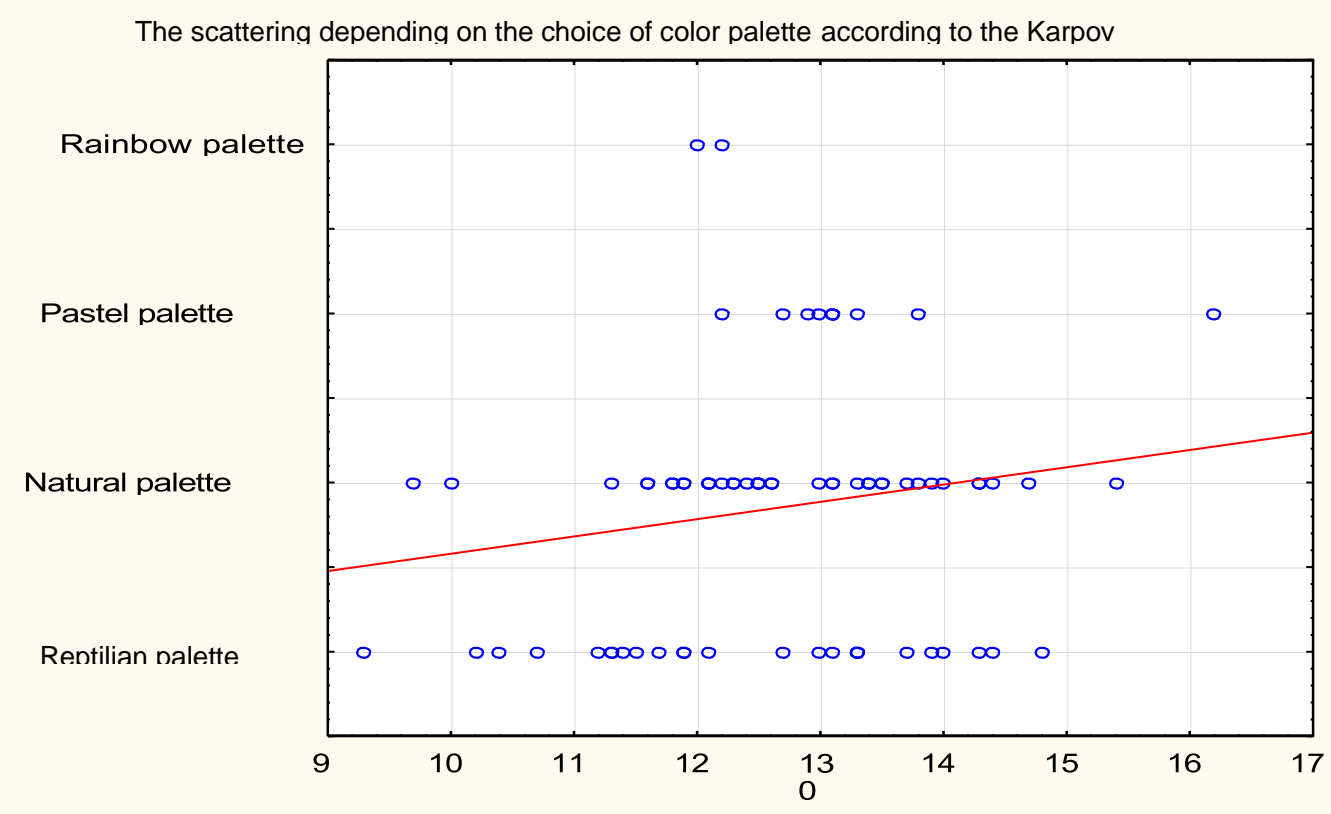

Based on the analysis, the following conclusions can be drawn:

- In the essays of students having a high reflexivity level, according to A.V. Karpov, emotional, cognitive and self-factor types of markers prevail, as well as emotional-asthenic, emotional-negative, cognitive-primary and cognitive-secondary markers subtypes. The total number of types of linguistic markers found in the essays also indicates the level of reflexivity of students. No markers were found that predominated in essays by students with low reflexivity.

- Essays by students with a high level of systemic reflexivity are dominated by bodilyenergetic and self-factor markers. In the essays by students with a low level of systemic reflexivity the markers are emotional and intellectual.

- Essays by students with a high level of introspection are dominated by emotionallynegative and bodily-energetic markers. In the essays of students with a low level of introspection the emotionally-positive and emotionally-intellectual markers prevail. 
- Essays by students with a high level of quasi reflexivity are dominated by emotionallynegative, cognitive primary, cognitive-secondary, bodily-energetic markers. Essays by students with a low level of quasi reflexivity are dominated by emotionally-positive markers.

- Bodily-energetic markers cannot be considered as specific for a particular type of reflexivity, since they are frequently encountered in the essays of students with all types of reflexivity according to $D$. A. Leontiev.

- We revealed the interdependence between individual marker words of reflexivity and types of reflexivity by D.A. Leontiev. The individual words highlighted as a result of the study, used in written or oral speech, with some degree of probability may indicate the severity of one or another type of reflexivity. Noteworthy are words characterizing the presence or absence of systemic reflexivity. In particular, evaluativeness, reference to past experience, and coercion indicate a low level of systemic reflexivity.

As an additional direction of research, it was revealed that with an increase in the level of reflexivity according to A.V. Karpov, the presence of a finished image and unpainted areas in a drawing is less common in students' drawings. With an increase in introspection and quasi reflexivity, less time is spent on the task, with more strokes / cells in the drawings.

\title{
CONCLUSION
}

We conducted a phenomenological study of the essays by students in art therapy trainings, for the presence of linguistic markers that might indicate different levels and types of reflexivity. We identified the specifics of the representation of linguistic markers among students with different reflexivity levels according to A.V. Karpov, and the occurrence of linguistic markers among students with different levels of such types of reflexivity as systemic reflexivity, introspection and quasi reflexivity according to D.A. Leontiev.

The results of this study confirmed the hypotheses that formed the basis of the experimental work. Differences in the presented linguistic markers in the essays of students with different types and levels of reflexivity were revealed. Special attention should be paid to both word groups and individual words that characterize systemic reflexivity as a personality trait that requires special conditions for its formation.

The features of the relationship between reflexivity processes and the presence of linguistic markers in written feedback at the final stages of art therapy trainings certainly require further study.

Tracing of individual psycholinguistic markers can help to identify possible reflexive qualities of a person in the practice of an educational psychologist. The results obtained can be used in the work of an art therapist when conducting group trainings in order to assess and analyze feedbacks both in the course of training work and in analyzing the outcomes.

\begin{abstract}
Authors' Contributions: Marina Georgiyevna Sergeeva: conception and design, acquisition of data, analysis and interpretation of data, drafting the article, critical review of important intellectual content. Andrei Anatolievich Kochin: conception and design, acquisition of data, analysis and interpretation of data, drafting the article, critical review of important intellectual content. Dmitry Vladimirovich Lukashenko: conception and design, acquisition of data, analysis and interpretation of data, drafting the article, critical review of important intellectual content. Ekaterina Vladislavovna Kozhina: conception and design, acquisition of data, analysis and interpretation of data, drafting the article, critical review of important intellectual content. All authors have read and approved the final version of the manuscript.
\end{abstract}

Ethics Approval: Not applicable.

Acknowledgments: Not applicable. 


\section{REFERENCES}

Ananiev, B. G. (1996). The structure of the development of psychophysiological functions of an adult. Selected psychological works, 1, 200-206.

Bírová, J., Kružlík, P., Kalimullin, A., Sokolova, N., Haroun, Z., Králik, R., \& Vasbieva, D. (2018). Mathematical and statistical bibliometric indicators for scholars in the field of romance languages and linguistics. EURASIA: Journal of Mathematics, Science and Technology Education, 14(12), em1638. https://doi.org/10.29333/ejmste/97826

Blinova, S., Dugina, T., \& Zabolotskikh, A. (2018). Teaching mixed nationality groups (on the example of students from the Northern Caucasus region). In: INTED2018: Proceedings of the 12th International Technology, Education and Development Conference, Valencia, Spain, March 5-7, 2018, pp. 7977-7982.

Chalikova, O. S. (2017) Personal predictors of professional success of technical specialists. Proceedings of the Ural Federal University. Series 1: problems of education, science and culture, 23(1(159)), 86-92.

Dolzhich, E., \& Dmitrichenkova, S. (2018). Computer science terminology (a case study of the Spanish language). In: INTED2018: Proceedings of the 12th International Technology, Education and Development Conference, Valencia, Spain, March 5-7, 2018, pp. 2556-2559.

Dubrovina, I. V. (2009). Psychological service in modern education: workbook. Saint Petersburg: Publishing House Peter, $400 \mathrm{p}$.

Gorev, P., Telegina, N., Karavanova, L., \& Feshina, S. (2018). Puzzles as a didactic tool for development of mathematical abilities of junior schoolchildren in basic and additional mathematical education. EURASIA: Journal of Mathematics, Science and Technology Education, 14(10), 178-185. https://doi.org/10.29333/ejmste/93675

Gromova, L. Yu., \& Tekucheva, I. V. (2017). On some general purpose of teaching the Russian language. Prospects for Science, 5(92), 65-68.

Karpov, A. V. (2006). Book about the inner world of man. Questions of psychology, 5, 177-179.

Koldochevsky, D. E. (2017). Linguistic markers of reflection as an indicator of psychological health (on the example of art therapy groups): graduation paper 37.04.01. The first President of Russia B. N. Yeltsin Ural. Feder. University, Yekaterinburg, $120 \mathrm{p}$.

Leontiev, D. A. (2011). New guidelines for understanding personality in psychology: from the necessary to the possible. Questions of psychology, 1, 3-27.

Sharonova, S., Trubnikova, N., \& Sokolova, N. (2018). Interpreting religious symbols as basic component of social value formation. European Journal of Science and Theology, 14(3), 117-129.

Tekucheva, I. V. (2006). Theory and methods of teaching the Russian language. Practical training: guidelines. Moscow: Moscow Humanitarian Pedagogical institute.

Tekucheva, I. V. (2018). On the basic category "teaching method" in textbooks on the methodology of teaching the Russian language at the beginning of the 20th century. Bulletin of the Moscow State Regional University. Series: Pedagogy, 1, 82-90.

Tekucheva, I. V., \& Gromova, L. Yu. (2015). Teaching to read: the historical aspect of the problem. In: Education, science and economics in universities and schools. Integration into the international educational space. Proceedings of the international scientific conference, Goris, Armenia, September 28 - October 2, 2015, pp. 381-385.

Tekucheva, I. V., \& Gromova, L. Y. (2016). On present state of teaching Russian language in Russia. International Journal of Environmental and Science Education, 11(14), 6504-6511.

Vasbieva, D. G., Sokolova, N. L., Masalimova, A. R., Shinkaruk, V. M., \& Kiva-Khamzina, Y. L. (2018). Exploring the EFL teacher's role in a smart learning environment - a review study. XLinguae, 11(2), 265-274.

https://doi.org/10.18355/XL.2018.11.02.21

Volkova, Y., \& Panchenko, N. (2018). Discourse variation of the concepts of destructive emotions. Vestnik Rossiiskogo Universiteta Druzhby Narodov. Russian journal of linguistics, 22(1), 175-194. https://doi.org/10.22363/2312-9182-

2018-22-1-175-194

Received: 31 May 2021 | Accepted: 2 August 2021 | Published: 24 August 2021

This is an Open Access article distributed under the terms of the Creative Commons Attribution License, which permits unrestricted use, distribution, and reproduction in any medium, provided the original work is properly cited. 